\title{
Construction safety management accidents, laws and practices in Kuwait
}

\author{
H. M. Al-Humaidi ${ }^{1} \&$ F. Hadipriono Tan $^{2}$ \\ ${ }^{I}$ Department of Civil Engineering, Kuwait University, Kuwait \\ ${ }^{2}$ Department of Civil Engineering, The Ohio State University, USA
}

\begin{abstract}
In Kuwait, the construction process can be very challenging due to the diverse labour force. In this paper, we analyze construction-related accidents in Kuwait that includes the type of accident, types of injury, the body part injured, and accident outcome for the years 1996-2007. As this research illustrates, the construction industry is the most hazardous industry in Kuwait. On average, falls are the major type of accident $(33.2 \%)$, followed by being crushed or struck by a falling object $(25.2 \%)$. Use or misuse of tools caused the third largest number of accidents in Kuwait (18.1\%). The most frequent type of injury is fractures $(52.6 \%)$ and the most common injured body part is the upper-body (53.4\%). An average of $(82.7 \%)$ of victims of construction accidents in Kuwait sustains permanent disabilities. Kuwaiti rules and legislation are discussed in this paper and suggestions for ensuring a safer construction environment are introduced. It is a fact that the Kuwaiti construction industry has a safety problem and that there is a need to change current legislation and control strategies in construction and building sites to more rigorous legislations and control practices to enhance construction safety level in Kuwait.
\end{abstract}

Keywords: construction safety, construction accidents, international construction, Kuwait.

\section{Introduction}

Workplace accidents have become a major concern in the construction industry since human loss can never be recovered. Accident victims face enormous personal difficulties, and suffer in dealing with the consequences of an accident. 
Generally, challenges to safe construction practices can be identified into three major challenges. First, measurement of safety is difficult, since obtaining a safe site depends on subjective judgment of personal definition of safety. In general, no process can be termed "safe" in an absolute sense. Resources devoted to maintaining safe environment are measurable with monetary value, but after devoting such resources the question of "Is the safety process safe?" still arises. Second, human error is non controllable, and individuals can only be blamed for negligence and controllable circumstances within their responsibilities. Construction projects can be very complex and fragmented by nature, since many parties work together to achieve desired outcomes; therefore matching responsibilities with control is extremely difficult. Third, projects are unique and temporary by nature; therefore adopting a standardized procedure that implement lessons learned from prior projects experiences can result in failure to predict new sources of hazards, depending on the nature of the project. Given these difficulties, implementation of general safety management procedures to assure a safe work environment is impossible.

For the purpose of studying the construction safety performance in Kuwait, data were obtained from the Ministry of Social Affairs and Labour (MSAL). Also, safety rules and regulations have been studies to evaluate them and to suggest improvements to legislation and control practices.

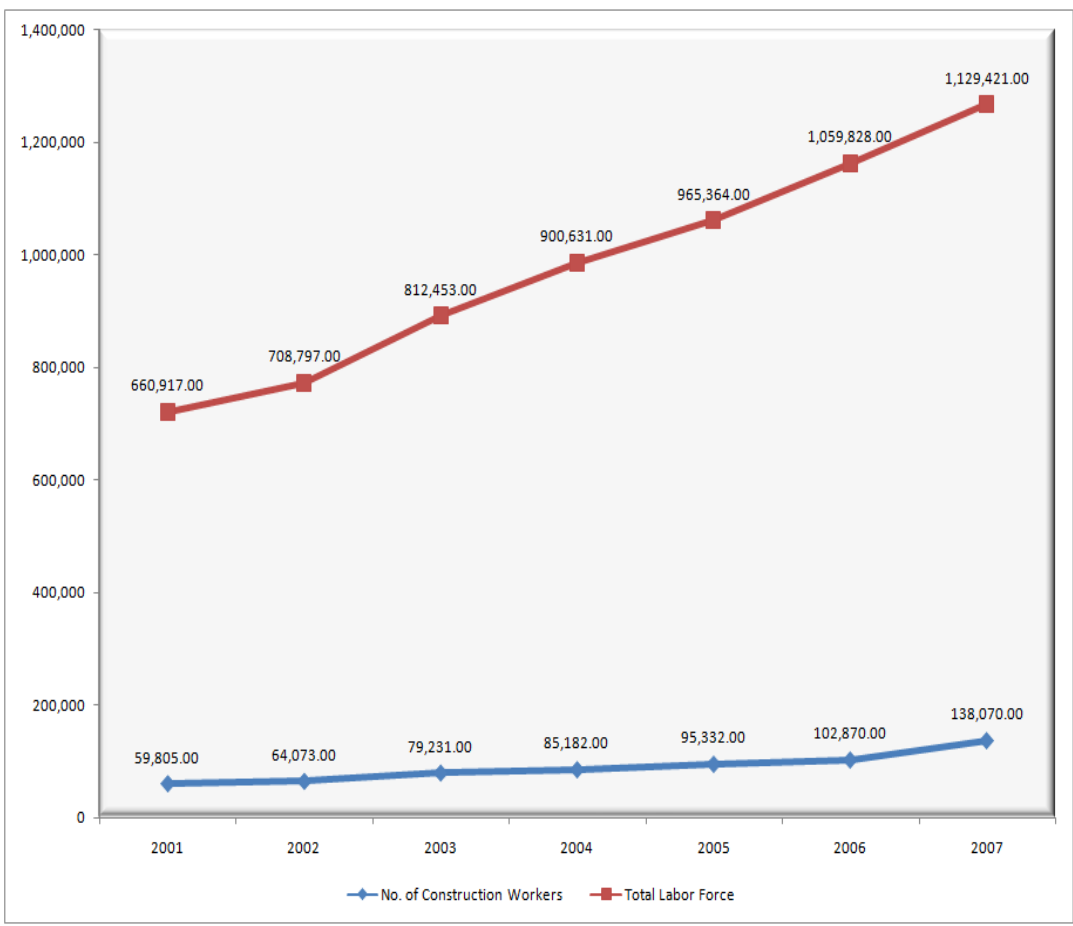

Figure 1: Number of total labour force and construction labour force in Kuwait. 


\section{Construction labour force in Kuwait}

Information obtained from MSAL reveals a consistent growth of the labour force. Construction workers make up approximately 9.9 percent of the total labour force for the years 2001 to 2007. Fig. 1 shows the trend for the number of total labour force in Kuwait and the number of construction labour force in Kuwait. Most of the construction labour force is comprised of foreign nationals from Asia, and these workers accept low-paying construction jobs because of the poverty they endure in their home countries. Most construction workers in Kuwait have very limited education; some workers barely read and write. Often, these workers lack the training necessary to perform complicated construction tasks. Because the majority of the construction labour force comes from countries in South Asia, these workers do not speak the local language.

\section{Construction accidents in Kuwait}

According to MSAL statistics, the construction industry has been responsible for the majority of worker injuries between 1996 and 2007. Fig. 2 shows the

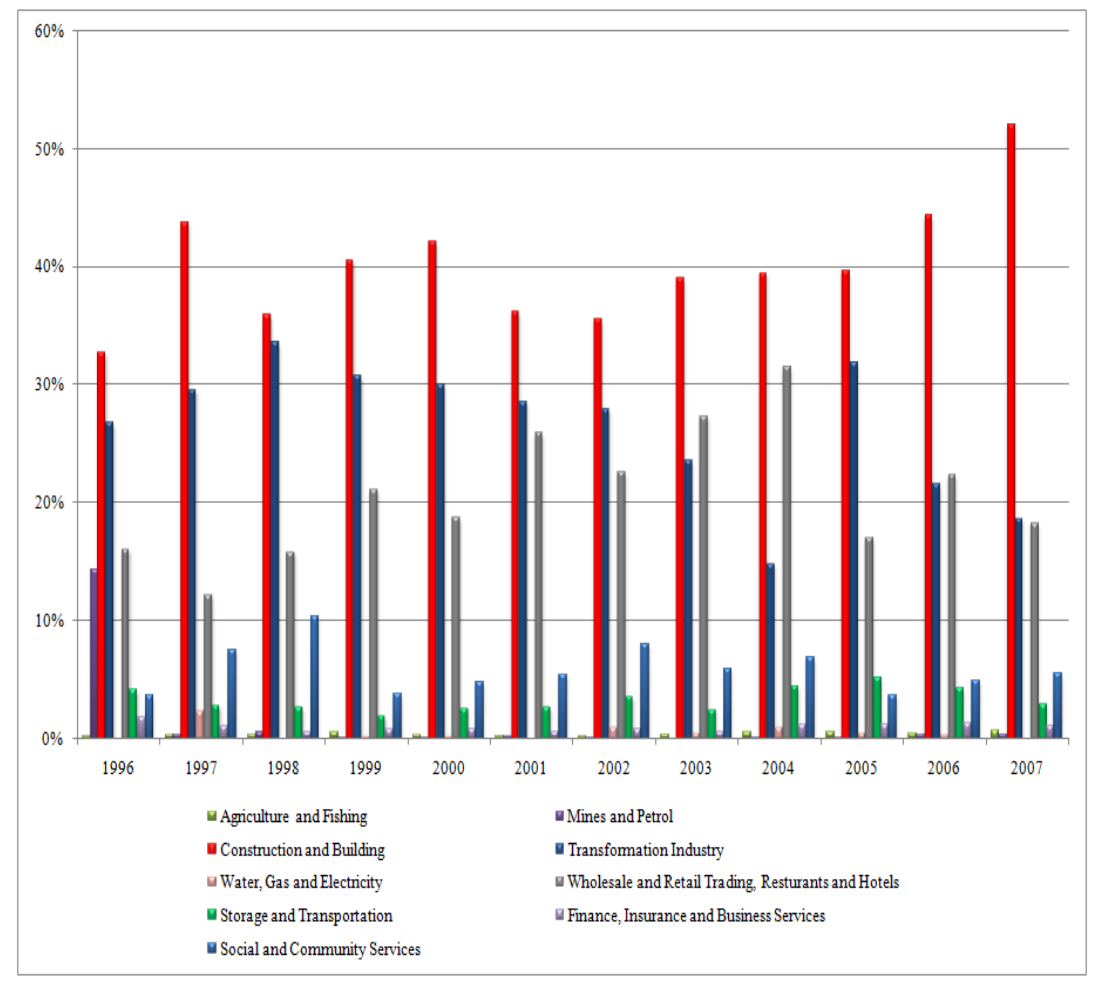

Figure 2: $\quad$ Percentages of accidents according to industry, 1996 to 2007. 
percentages of workplace accidents reported by various industries for the years 1996 through 2007.

MSAL provided data for construction accidents for the years 1996-2007. MSAL did not report data from 1998 for unknown reasons. Tables 1-3 show construction-related accidents classified by type of accident, type of injury, injured body part, and outcome for the years from 1996-97, and 1999-2007. On the average, falls are the most frequently occurring accident $(33.2 \%)$, followed by being crushed or struck by an object (25.2\%). Accidents caused by the use or misuse of tools are the third most frequent accidents $(18.1 \%)$. Fractures are the most common injury for construction workers $(52.6 \%)$, followed by wounds $(17.5 \%)$, and bruises (14.5\%). Most construction injuries affect the upper part of the body (53.4\%), followed by lower part of the body $(32.8 \%)$. Miscellaneous accidents involving injury to more than one organ comprised $4.4 \%$ of reported accidents. On average, $82.7 \%$ of non-fatal construction accidents in Kuwait result in permanent disabilities; $16.5 \%$ of construction accident victims make a full recovery and $0.8 \%$ of Kuwaiti construction accidents result in fatalities. After examining data for construction-related accidents of the last ten years, it is obvious that construction sites in Kuwait lack safety standards, and that there is a pressing need to change current construction practices with respect to safety. The data shows a need for improvement of safety on Kuwaiti construction sites for humanitarian reasons.

\section{Current practices and legislation}

The population of Kuwait is 2.5 million, including 1.3 million foreign residents, making foreign residents more than $52 \%$ of the population (CIA World Fact Book 2008) [1]. Kuwaiti labour law covers labour rights. MSAL is responsible for the application of rules and regulations specified in Kuwaiti labour law. By examining the law, the following points were considered. According to Kuwaiti labour law, the right to join the labour trade union is confined to Kuwaiti citizens (Chapter XIII, Kuwait Private Sector, Kuwait Labour Law) [2]. Given that most workers on construction sites are non-Kuwaitis, the law fails to cover their rights.

Article 95, Chapter XV, of the general provisions of Kuwaiti private sector labour law states clearly that officials of MSAL have the right to inspect and supervise the execution of laws and implementation of labour safety rights. Most contractors agree that such inspections never take place and safety inspections are made by site engineers that work for the owner or the owner's representative. Kuwaiti labour law specifies that injury disputes be made solely on behalf of trade union members, that is, Kuwaiti Labourers, which fails to cover the rights of non-Kuwaiti labourers. Citations amount ranges between Kuwaiti Dinar 100 to 200 Equivalent to $\$ 360$ to $\$ 720$ for each worker that the citation affects. Many professionals interviewed believe that an increase in the monetary amount of the citation would help increase safety on site. 
Table 1: $\quad$ Construction-related accidents for years 1996, 1997, and 19992001.

\begin{tabular}{|c|c|c|c|c|c|c|c|c|c|c|}
\hline \multicolumn{11}{|c|}{ Construction-Related Accidents in Kuwait (1996-1997, 1999-2001) } \\
\hline & \multicolumn{2}{|c|}{$\underline{1996}$} & \multicolumn{2}{|c|}{1997} & \multicolumn{2}{|c|}{$\underline{1999}$} & \multicolumn{2}{|c|}{$\underline{2000}$} & \multicolumn{2}{|c|}{2001} \\
\hline & No. & $\%$ & No. & $\%$ & No. & $\%$ & No. & $\%$ & No. & $\%$ \\
\hline \multicolumn{11}{|l|}{$\begin{array}{l}\text { Type of } \\
\text { Accident }\end{array}$} \\
\hline Falls & 297 & 21.4 & 378 & 28.8 & 391 & 31.5 & 332 & 34.2 & 244 & 34.5 \\
\hline $\begin{array}{l}\text { Crushed or } \\
\text { struck by } \\
\text { object }\end{array}$ & 365 & 26.4 & 290 & 22.1 & 343 & 27.7 & 255 & 26.3 & 179 & 25.3 \\
\hline Overexertion & 60 & 4.3 & 103 & 7.9 & 37 & 3.0 & 41 & 4.2 & 22 & 3.1 \\
\hline $\begin{array}{l}\text { Use or misuse } \\
\text { of tools }\end{array}$ & 246 & 17.8 & 281 & 21.4 & 253 & 20.4 & 168 & 17.3 & 134 & 18.9 \\
\hline $\begin{array}{l}\text { Debris- } \\
\text { caused }\end{array}$ & 104 & 7.5 & 107 & 8.2 & 50 & 4.0 & 23 & 2.4 & 20 & 2.8 \\
\hline $\begin{array}{l}\text { Electric } \\
\text { shock }\end{array}$ & 9 & 0.6 & 9 & 0.7 & 8 & 0.6 & 17 & 1.8 & 9 & 1.3 \\
\hline $\begin{array}{l}\text { Fire/ } \\
\text { explosion }\end{array}$ & 11 & 0.8 & 13 & 1.0 & 16 & 1.3 & 13 & 1.3 & 6 & 0.8 \\
\hline $\begin{array}{l}\text { Heavy } \\
\text { equipment }\end{array}$ & 57 & 4.1 & 63 & 4.8 & 38 & 3.1 & 46 & 4.7 & 40 & 5.6 \\
\hline $\begin{array}{l}\text { Chemicals/ } \\
\text { poisoning }\end{array}$ & 15 & 1.1 & 2 & 0.2 & 2 & 0.2 & 1 & 0.1 & 1 & 0.1 \\
\hline Asphyxiation & 0 & 0.0 & 0 & 0.0 & 19 & 1.5 & 24 & 2.5 & 9 & 1.3 \\
\hline Automobile & 0 & 0.0 & 0 & 0.0 & 42 & 3.4 & 30 & 3.1 & 14 & 2.0 \\
\hline Other & 221 & 16.0 & 65 & 5.0 & 41 & 3.3 & 20 & 2.1 & 30 & 4.2 \\
\hline Total & 1385 & & 1311 & & 1240 & & 970 & & 708 & \\
\hline \multicolumn{11}{|l|}{ Type of injury } \\
\hline Amputation & 59 & 4.3 & 54 & 4.1 & 67 & 5.4 & 49 & 5.1 & 28 & 4.0 \\
\hline Wounds & 302 & 21.8 & 344 & 26.2 & 231 & 18.6 & 164 & 16.9 & 96 & 13.6 \\
\hline Fractures & 612 & 44.2 & 591 & 45.1 & 615 & 49.6 & 547 & 56.4 & 435 & 61.4 \\
\hline Bruises & 161 & 11.6 & 168 & 12.8 & 200 & 16.1 & 125 & 12.9 & 90 & 12.7 \\
\hline Burns & 42 & 3.0 & 15 & 1.1 & 22 & 1.8 & 20 & 2.1 & 17 & 2.4 \\
\hline Other & 209 & 15.1 & 139 & 10.6 & 105 & 8.5 & 65 & 6.7 & 42 & 5.9 \\
\hline Total & 1385 & & 1311 & & 1240 & & 970 & & 708 & \\
\hline \multicolumn{11}{|c|}{ Injured body part } \\
\hline Head & 58 & 4.2 & 48 & 3.7 & 54 & 4.4 & 25 & 2.6 & 25 & 3.5 \\
\hline Eye & 43 & 3.1 & 99 & 7.6 & 50 & 4.0 & 26 & 2.7 & 15 & 2.1 \\
\hline Upper body & 809 & 58.4 & 646 & 49.3 & 639 & 51.5 & 575 & 59.3 & 395 & 55.8 \\
\hline Lower body & 423 & 30.5 & 401 & 30.6 & 396 & 31.9 & 267 & 27.5 & 222 & 31.4 \\
\hline Torso & 33 & 2.4 & 63 & 4.8 & 50 & 4.0 & 37 & 3.8 & 21 & 3.0 \\
\hline Miscellaneous & 19 & 1.4 & 54 & 4.1 & 51 & 4.1 & 40 & 4.1 & 30 & 4.2 \\
\hline Total & 1385 & & 1311 & & 1240 & & 970 & & 708 & \\
\hline \multicolumn{11}{|l|}{ Outcome } \\
\hline Full recovery & 372 & 26.9 & 419 & 32.0 & 268 & 21.6 & 197 & 20.3 & 141 & 19.9 \\
\hline $\begin{array}{l}\text { Permanent } \\
\text { Disability }\end{array}$ & 1005 & 72.6 & 882 & 67.3 & 967 & 78.0 & 767 & 79.1 & 559 & 79.0 \\
\hline Death & 8 & 0.6 & 10 & 0.8 & 5 & 0.4 & 6 & 0.6 & 8 & 1.1 \\
\hline Total & 1385 & & 1311 & & 1240 & & 970 & & 708 & \\
\hline
\end{tabular}


Table 2: $\quad$ Construction-related accidents for years 2002-2006.

\begin{tabular}{|c|c|c|c|c|c|c|c|c|c|c|}
\hline \multicolumn{11}{|c|}{ Construction-Related Accidents in Kuwait (2002-2006) } \\
\hline & \multicolumn{2}{|c|}{2002} & \multicolumn{2}{|c|}{2003} & \multicolumn{2}{|c|}{2004} & \multicolumn{2}{|c|}{2005} & \multicolumn{2}{|c|}{2006} \\
\hline & No. & $\%$ & No. & $\%$ & No. & $\%$ & No. & $\%$ & No. & $\%$ \\
\hline \multicolumn{11}{|c|}{ Type of Accident } \\
\hline Falls & 340 & 33.4 & 363 & 29.0 & 277 & 31.8 & 331 & 29.0 & 512 & 40.9 \\
\hline $\begin{array}{l}\text { Crushed or } \\
\text { struck by } \\
\text { object }\end{array}$ & 251 & 24.6 & 380 & 30.4 & 242 & 27.8 & 135 & 11.8 & 329 & 26.3 \\
\hline $\begin{array}{l}\text { Over- } \\
\text { exertion }\end{array}$ & 16 & 1.6 & 21 & 1.7 & 53 & 6.1 & 289 & 25.3 & 11 & 0.9 \\
\hline $\begin{array}{l}\text { Use or } \\
\text { misuse of } \\
\text { tools }\end{array}$ & 227 & 22.3 & 242 & 19.3 & 205 & 23.5 & 194 & 17.0 & 193 & 15.4 \\
\hline $\begin{array}{l}\text { Debris- } \\
\text { caused }\end{array}$ & 20 & 2.0 & 33 & 2.6 & 7 & 0.8 & 14 & 1.2 & 20 & 1.6 \\
\hline $\begin{array}{l}\text { Electric } \\
\text { shock }\end{array}$ & 7 & 0.7 & 2 & 0.2 & 2 & 0.2 & 6 & 0.5 & 1 & 0.1 \\
\hline $\begin{array}{l}\text { Fire/ } \\
\text { explosion }\end{array}$ & 25 & 2.5 & 16 & 1.3 & 6 & 0.7 & 7 & 0.6 & 18 & 1.4 \\
\hline $\begin{array}{l}\text { Heavy } \\
\text { equipment }\end{array}$ & 40 & 3.9 & 38 & 3.0 & 17 & 2.0 & 73 & 6.4 & 15 & 1.2 \\
\hline $\begin{array}{l}\text { Chemicals/ } \\
\text { poisoning }\end{array}$ & 3 & 0.3 & 1 & 0.1 & 0 & 0.0 & 1 & 0.1 & 1 & 0.1 \\
\hline Asphyxiation & 19 & 1.9 & 27 & 2.2 & 10 & 1.1 & 9 & 0.8 & 24 & 1.9 \\
\hline Automobile & 41 & 4.0 & 56 & 4.5 & 26 & 3.0 & 50 & 4.4 & 59 & 4.7 \\
\hline Other & 30 & 2.9 & 72 & 5.8 & 26 & 3.0 & 32 & 2.8 & 69 & 5.5 \\
\hline Total & 1019 & & 1251 & & 871 & & 1141 & & 1252 & \\
\hline \multicolumn{11}{|l|}{ Type of injury } \\
\hline Amputation & 50 & 4.9 & 71 & 5.7 & 39 & 4.5 & 58 & 5.1 & 44 & 3.5 \\
\hline Wounds & 142 & 13.9 & 213 & 17.0 & 147 & 16.9 & 211 & 18.5 & 174 & 13.9 \\
\hline Fractures & 620 & 60.8 & 643 & 51.4 & 487 & 55.9 & 626 & 54.9 & 652 & 52.1 \\
\hline Bruises & 104 & 10.2 & 184 & 14.7 & 127 & 14.6 & 157 & 13.8 & 230 & 18.4 \\
\hline Burns & 23 & 2.3 & 20 & 1.6 & 8 & 0.9 & 10 & 0.9 & 22 & 1.8 \\
\hline Other & 80 & 7.9 & 120 & 9.6 & 63 & 7.2 & 79 & 6.9 & 130 & 10.4 \\
\hline Total & 1019 & & 1251 & & 871 & & 1141 & & 1252 & \\
\hline \multicolumn{11}{|c|}{ Injured Body Part } \\
\hline Head & 22 & 2.2 & 38 & 3.0 & 25 & 2.9 & 24 & 2.1 & 39 & 3.1 \\
\hline Eye & 23 & 2.3 & 30 & 2.4 & 12 & 1.4 & 14 & 1.2 & 17 & 1.4 \\
\hline Upper body & 592 & 58.1 & 661 & 52.8 & 476 & 54.6 & 512 & 44.9 & 633 & 50.6 \\
\hline Lower body & 284 & 27.9 & 374 & 29.9 & 289 & 33.2 & 497 & 43.6 & 454 & 36.3 \\
\hline Torso & 48 & 4.7 & 53 & 4.2 & 32 & 3.7 & 34 & 3.0 & 41 & 3.3 \\
\hline $\begin{array}{l}\text { Miscellaneo } \\
\text { us }\end{array}$ & 50 & 4.9 & 95 & 7.6 & 37 & 4.2 & 60 & 5.3 & 68 & 5.4 \\
\hline Total & 1019 & & 1251 & & 871 & & 1141 & & 1252 & \\
\hline \multicolumn{11}{|l|}{ Outcome } \\
\hline $\begin{array}{l}\text { Full } \\
\text { recovery }\end{array}$ & 112 & 11.0 & 173 & 13.8 & 103 & 11.8 & 34 & 3.0 & 156 & 12.5 \\
\hline $\begin{array}{l}\text { Permanent } \\
\text { Disability }\end{array}$ & 899 & 88.2 & 1064 & 85.1 & 767 & 88.1 & 1091 & 95.6 & 1072 & 85.6 \\
\hline Death & 8 & 0.8 & 14 & 1.1 & 1 & 0.1 & 16 & 1.4 & 24 & 1.9 \\
\hline Total & 1019 & & 1251 & & 871 & & 1141 & & 1252 & \\
\hline
\end{tabular}


Table 3: $\quad$ Construction-related accidents for year 2007.

\begin{tabular}{|c|c|c|c|c|}
\hline \multicolumn{5}{|c|}{ Construction-Related Accidents in Kuwait (2007) } \\
\hline & \multicolumn{2}{|c|}{$\underline{2007}$} & \multicolumn{2}{|c|}{ Total } \\
\hline & No. & $\%$ & No. & $\%$ \\
\hline \multicolumn{5}{|l|}{ Type of Accident } \\
\hline Falls & 817 & 46.16 & 4282 & 33.2 \\
\hline $\begin{array}{l}\text { Crushed or struck b } \\
\text { object }\end{array}$ & 483 & 27.3 & 3252 & 25.2 \\
\hline Over-exertion & 27 & 1.5 & 680 & 5.3 \\
\hline $\begin{array}{l}\text { Use or misuse of } \\
\text { tools }\end{array}$ & 193 & 10.9 & 2336 & 18.1 \\
\hline Debris-caused & 18 & 1.0 & 416 & 3.2 \\
\hline Electric shock & 1 & 0.1 & 71 & 0.6 \\
\hline Fire/ explosion & 17 & 1.04 & 148 & 1.2 \\
\hline Heavy equipment & 8 & 0.5 & 435 & 3.4 \\
\hline Chemicals/poisoning & 1 & 0.1 & 28 & 0.2 \\
\hline Asphyxiation & 30 & 1.7 & 171 & 1.3 \\
\hline Automobile & 52 & 3.0 & 370 & 2.9 \\
\hline Other & 123 & 7.0 & 729 & 5.6 \\
\hline Total & 1770 & & 12918 & \\
\hline \multicolumn{5}{|l|}{ Type of injury } \\
\hline Amputation & 92 & 5.2 & 611 & 4.7 \\
\hline Wounds & 239 & 13.5 & 2263 & 17.5 \\
\hline Fractures & 965 & 54.5 & 6793 & 52.6 \\
\hline Bruises & 331 & 18.7 & 1877 & 14.5 \\
\hline Burns & 27 & 1.5 & 226 & 1.8 \\
\hline Other & 116 & 6.6 & 1148 & 8.9 \\
\hline Total & 1770 & & 12918 & \\
\hline \multicolumn{5}{|l|}{ Injured Body Part } \\
\hline Head & 20 & 1.1 & 378 & 2.9 \\
\hline Eye & 29 & 1.6 & 358 & 2.8 \\
\hline Upper body & 958 & 54.1 & 6896 & 53.4 \\
\hline Lower body & 642 & 36.3 & 4249 & 32.9 \\
\hline Torso & 58 & 3.3 & 470 & 3.6 \\
\hline Miscellaneous & 63 & 3.6 & 567 & 4.4 \\
\hline Total & 1770 & & 12918 & \\
\hline \multicolumn{5}{|l|}{ Outcome } \\
\hline Full recovery & 151 & 8.5 & 2126 & 16.5 \\
\hline $\begin{array}{l}\text { Permanent } \\
\text { Disability }\end{array}$ & 1614 & 91.2 & 10687 & 82.7 \\
\hline Death & 5 & 0.3 & 105 & 0.8 \\
\hline Total & 1770 & & 12918 & \\
\hline
\end{tabular}

According to the law, injuries suffered by labourers during normal working hours are classified into three categories, injuries, permanent disabilities, and deaths. In cases of injury, the worker is compensated according to the number of days needed for recovery recommended by medical examination. In cases of permanent disability, the labourer is compensated for the percentage of disability determined by the medical board (percent disability $x$ salary $\times 2000$ days) or a 
compensation of approximately Kuwaiti Dinar $(10,000+1 / 3 \times 10,000)=13,333$ equivalent to $\$ 48,000$, whichever is greater. In the event of death, the labourer is entitled to a full pay for 1500 days or up to a maximum amount of KD 10,000. According to insurance company representatives, insurance covers most injuries and compensates workers because competition among insurance companies is very high and monetary compensation of injuries is minimal. Low monetary citation value is correlated to poor safety practices in construction sites in Kuwait.

On-site safety standards are specified in the conditions of the contract, to which the project parties agree. Some projects specify British Safety Standards; others follow the Occupational Safety and Health Administration (OSHA) regulations. Kuwaiti safety standards do not comply with international codes and standards. Lack of codes and standards that account for current construction operations in Kuwait contribute to safety problems and impede efforts to improve safety on Kuwaiti construction sites. The existing code was included in Kuwait labour law published in 1964 and amended in 1997. In international construction related projects that include international stakeholders, international safety standards are followed due to international rules which mandate international standards.

Different government authorities measure the safety of Kuwaiti construction sites, including the Administration of Safety at Kuwait Municipality (KM) and the Worker's Affair Department at the Ministry of Social Affairs and Labour (MSAL); however, these authorities limit their sharing of information. Furthermore, the different authorities do not provide detailed reports of accidents. The data they provide only accounts for reported accidents, and they do not provide for the investigation of the causes of accidents. Furthermore, communication between the Ministry of Social Affairs and Labour (MSAL) and the Kuwait Municipality is lacking and the Kuwaiti government does not maintain a complete database of construction related accidents. According to OSHA, a competent person is a person who can identify existing or potential hazards and has authority to take corrective actions to eliminate them [14]. Such competent persons are typically absent from Kuwaiti construction sites; typically, they are replaced by site engineers who lack safety training, cannot identify potential hazards, or are constrained by limited resources, especially in very tight budget projects.

Although safety engineers hired by the Kuwait Municipality (KM) to conduct daily inspections on safety in construction sites have the authority to issue safety violations and warnings to contractors who adopt unsafe practices, few violations are recorded according to the Kuwait Municipality records and if such violations are issued, the citation value is very low. Typical construction workers are uneducated and often have communication problems owing to their inability as foreigners to the local language. In addition, most construction workers come to Kuwait from very poor societies without their families, and such conditions can become very stressful and may result in negligence and accidents. On most construction sites, inspection of construction equipment is limited; such a practice may contribute to accidents. In 2005, the Ministry of Social Affairs and 
Labour passed a new law that prohibits workers from working in urban climate between 12 noon and 4 pm during the months of June, July and August. This legislation helps prevent dehydration of workers due to summer hot weather. The International Labour Organization has been putting pressure on the Ministry of Social Affairs and Labour to protect the rights of foreign labourers, but no legislation has been passed.

\section{Conclusion}

The construction industry in Kuwait faces a safety problem, as construction workers account for an average of $40.09 \%$ of all work-related injuries for the years 1996, 1997, and 1999 to 2007. Construction workers are most often injured in falls, followed by being crushed or hit by falling objects. Injuries resulting from the use or misuse of tools are next common occurrences. Untrained workers on Kuwaiti construction sites cause many accidents. Improvement of on-site supervision and control should prevent accidents. Safety management and planning is needed to prevent unsafe working conditions. Minimal monetary settlement of injury and death cases contributes to the negligence of contractors and subcontractors. In Kuwait, rules regarding compensation of workers injured or killed in accidents need to be modified. Labour unions are needed in Kuwait to protect the rights of labourers. A single authority equivalent to a competent person as defined by OSHA regulations who is responsible for safety on construction sites is needed. A detailed database of all construction-related accidents and the results of investigations into the causes of accidents would help improve on-site safety practices and minimize future accidents. Local codes and legislation of on-site safety practices will also improve safety on construction sites.

An analysis of the statistics related to construction accidents in Kuwait reveals the extent of the safety problems on construction sites. We believe that management, site engineers and construction workers need safety education to emphasize its importance at different levels. An accident database with investigation of accidents to be shared among different Kuwaiti authorities and a single centre responsible for construction project safety should be established. Furthermore, employers must begin to train all employees on site to recognize developing hazards; employers must ensure that a competent person performs designated duties of the position. Periodic site inspections to ensure safety precautions are undertaken should be conducted. Improvement of local codes and legislation increasing construction-site safety are needed. Additionally, safety legislation and codes can be improved if the mistakes that resulted in accidents are considered.

\section{Acknowledgements}

The writers would like to thank everyone who provided information for this research. The writers would like to thank Miss Batla Al-Ajmi, Miss Samera Mandani Mr. Abdulaziz Taqi from the Ministry of Social Affairs and Labour for 
their help. Officials in the Kuwait Department of Fire, especially Mr. Mishari AlFaras, provided valuable information about construction accidents in Kuwait.

\section{References}

[1] Central Intelligence Agency. "The World Factbook," Retrieved Jan. 16, 2008, from https:/www.cia.gov/library/publications/the-world-factbook/.

[2] Kartam, N.A. and Bouz, R.G. (1998). "Fatalities and injuries in the Kuwaiti construction industry." Accident Analysis and Prevention, 30(6), 805-814.

[3] Kuwait Ministry of Social Affairs and Labour (1997). "New private sector labour law No. 38 of 1964 of state of Kuwait with amendments up to 1997'. Ministry of Social Affairs and Labour, Kuwait.

[4] Kuwait Ministry of Social Affairs and Labour (1997). "Private sector labour force statistics for the years 1996, 1997." Information and Statistics Department. Ministry of Social Affairs and Labour, Kuwait.

[5] Kuwait Ministry of Social Affairs and Labour (1999). "Private sector labour force statistics for the year 1999." Information and Statistics Department. Ministry of Social Affairs and Labour, Kuwait.

[6] Kuwait Ministry of Social Affairs and Labour (2000). "Private sector labour force statistics for the year 2000." Information and Statistics Department. Ministry of Social Affairs and Labour, Kuwait.

[7] Kuwait Ministry of Social Affairs and Labour (2001). "Private sector labour force statistics for the year 2001." Information and Statistics Department. Ministry of Social Affairs and Labour, Kuwait.

[8] Kuwait Ministry of Social Affairs and Labour (2002). "Private sector labour force statistics for the year 2002." Information and Statistics Department. Ministry of Social Affairs and Labour, Kuwait.

[9] Kuwait Ministry of Social Affairs and Labour (2003). "Private sector labour force statistics for the year 2003." Information and Statistics Department. Ministry of Social Affairs and Labour, Kuwait.

[10] Kuwait Ministry of Social Affairs and Labour (2004). "Private sector labour force statistics for the year 2004." Information and Statistics Department. Ministry of Social Affairs and Labour, Kuwait.

[11] Kuwait Ministry of Social Affairs and Labour (2005). "Private sector labour force statistics for the year 2005." Information and Statistics Department. Ministry of Social Affairs and Labour, Kuwait.

[12] Kuwait Ministry of Social Affairs and Labour (2006). "Private sector labour force statistics for the year 2006." Information and Statistics Department. Ministry of Social Affairs and Labour, Kuwait.

[13] Kuwait Ministry of Social Affairs and Labour (2007). "Private sector labour force statistics for the year 2007." Information and Statistics Department. Ministry of Social Affairs and Labour, Kuwait.

[14] Occupational Safety \& Health Administration. "US Department of Labour Occupational Safety \& Health Administration." Retrieved Jan. 16, 2008, from http://www.osha.gov. 